\title{
Acetylacetone-Based Electrolyte in Dye Sensitized Solar Cell
}

\author{
Masato Ohmukai ${ }^{1}$, Jun Kyokane ${ }^{2}$ \\ ${ }^{1}$ Department of Electrical and Computer Engineering, Akashi College of Technology, Akashi, Japan \\ ${ }^{2}$ Center for International Education Toyohashi University of Technology, Toyohashi, Japan \\ Email: ohmukai@akashi.ac.jp
}

How to cite this paper: Ohmukai, M. and Kyokane, J. (2017) Acetylacetone-Based Electrolyte in Dye Sensitized Solar Cell. World Journal of Engineering and Technology, 5, 428-434.

https://doi.org/10.4236/wjet.2017.53037

Received: June 24, 2017

Accepted: July 17, 2017

Published: July 20, 2017

Copyright ( 92017 by authors and Scientific Research Publishing Inc. This work is licensed under the Creative Commons Attribution International License (CC BY 4.0).

http://creativecommons.org/licenses/by/4.0/

\section{cc) (i) Open Access}

\begin{abstract}
Dye sensitized solar cells attract much attention for a clean energy generation device. Among several solvents for the electrolyte, we investigated here the cell characteristics with acetylacetone as a solvent. The electric conductivity of the electrolyte increases as the concentration of polyethylene glycol (PEG) decreases or that of ionic liquid increases. The addition of pyridine into the electrolyte improves both the open voltage and the short current density. On the other hand, the replacement of PEG with fluorinated oligomer in the gel electrolyte highly increases the short current density where the open voltage is not varied. As the concentration of ionic liquid increase, the open voltage and the short current density gradually increase. When more than $20 \mathrm{wt} . \%$ of the ionic liquid was mixed, the gelation was not obtained. As a result, acetylacetone is a practical solvent for a gel electrolyte with the fluorinated oligomer and ionic liquid.
\end{abstract}

\section{Keywords}

Ruthenium Ion Complex, Dye-Sensitized Solar Cell, Acetylacetone, Fluorinated Gel, Ionic Liquid

\section{Introduction}

Silicon solar cells are nowadays widely used in homes, factories and even electric power generating factories. The environment-friendly power generation will be more and more important in the future. A new type of solar cells that came into birth in 1990 is greatly worth paying attention to it. The study of dye-sensitized solar cells (DSCs) has been performed extensively so far [1] [2] [3] [4]. Even today, continuous efforts are being devoted to enlarge its conversion efficiency and durability [5].

The dye-sensitized solar cell can be divided into three parts: the cathode, the 
anode and the electrolyte between the two electrodes. The cathode consists of a light-incoming nanostructured electrode carrying dyes where light is devoted to the electron excitation. Since the dye holds the centered role in generating electric power, it has been fully investigated so far [3] [6] [7]. The photoelectrode has been also studied with regard to its microstructure [8]. The counter electrode, the anode, is also important because of the role of electron injection [3].

We focus on the electrolyte here. The key issue is the redox reaction of $I_{2}$ in it, or sometimes LiI is also involved. The effects of other solvents have been studied before. Hara et al. reported the open voltage and the short current density with a variety of solvent in the electrolyte [9]: acetonitrile, propionitrile, methoxyacetonitrile, methoxypropionitrile, benzonitrile, phenylacetonitrile, nitromethane, propylene carbonate, dimethoxyethane, dimethylsulfoxide, tetrahydrofuran, $\mathrm{N}, \mathrm{N}$-dimethylformamide, N-methyl-2-pyrolidone, six kinds of alcohol, and ethylene glycol. Their results showed acetonitrile gave the biggest short current density of $3.42 \mathrm{~mA} / \mathrm{cm}^{2}$. Acetonitrile is actually one of the solvent often used for the electrolyte. On the other hand, the biggest open voltage of $0.85 \mathrm{~V}$ was obtained from the cell with dimethylsulfoxide. Fukui et al. tried the mixing solvent in various combinations, and obtained the similar results that acetonitrile and dimethylsulfoxide gave the biggest short current density and open voltage [10]. We tried to use acetylacetone that has not attracted so much attention before. Acetylacetone is a simple molecular and can forms a various metal complexes at the same time. We expect it may expand the possibility of redox system in the electrolyte.

\section{Experimental Details}

We first describe the preparation of the cathode. The slurry containing titania particles whose dimension is between 50 and $75 \mathrm{~nm}$ was mixed for 15 minutes with polyethylene glycol (PEG) by $10 \mathrm{wt} . \%$ and titania powder of P-25 by 10 wt.\%. In order to enhance the viscosity, Triton X $(15 \mu \mathrm{l})$ was added and the mixture was well mixed for 15 minutes further to make paste. The paste was spread over a piece of fluorinated tin oxide (FTO) $(100 \mu \mathrm{m})$ on a glass substrate, annealed at $450^{\circ} \mathrm{C}$ for 30 minutes, and then cooled down naturally to room temperature. The obtained cathode was then soaked in Ruthenium dye complex $\left(\mathrm{RuL}_{2}(\mathrm{NCS})_{2}, \mathrm{~L}=4,4^{\prime}\right.$-dicarboxy-2,2'-biphridine) diluted in ethanol at $3 \times 10^{4} \mathrm{M}$ for three hours at room temperature. The anode was prepared in such a way that Pt was deposited by a sputtering method on another FTO glass plate. The thickness of the Pt layer was around $10 \mathrm{~nm}$.

The preparation of the electrolyte gel is described here. The mixture of acetylacetone and a kind of ionic liquid (1-ethyl-3-methylimidazolium tetrafluoroborate) was used as a solvent. Into this solvent, LiI was added by $2 \mathrm{wt} . \%$ of the solvent and the mixture was well mixed for 10 minutes. Finally it was gelated by adding PEG and sonicated for 90 minutes.

In addition, we performed the extra experiments that the ionic liquid was replaced by another ionic liquid of a butyl-imidazolium system. Additionally we 
tried that a fluorinated oligomer gel was used instead of PEG gel electrolyte.

The electric conductivity was determined on the basis of a Cole-Cole plot. The $J-V$ characteristics were measured under the irradiation of white light (AM 1.5) with a filtered light from a xenon lamp (UXL500SX by USHIO) at $55 \mathrm{~mW} / \mathrm{cm}^{2}$. The load resistance was varied in the range between 0 and $100 \mathrm{k} \Omega$.

\section{Results and Discussion}

Figure 1 shows the dependence of the electrical conductivity on PEG concentration. The concentration of ionic liquid to acetylacetone was fixed to be $15 \mathrm{wt} . \%$ here. As the PEG concentration increases, the electrical conductivity decreases monotonically. However, if the amount of PEG is not high enough, gelation cannot be achieved. There is rationally a trade-off between the gelation and conductivity because gelation means the enhancement of the viscosity which results in the difficulty in ionic movements. The gelation fundamentally conflicts with the high ionic conductivity in nature.

Figure 2 shows the relationship between the electric conductivity and the concentration of the ionic liquid. The concentration of PEG was fixed to $20 \mathrm{wt} . \%$

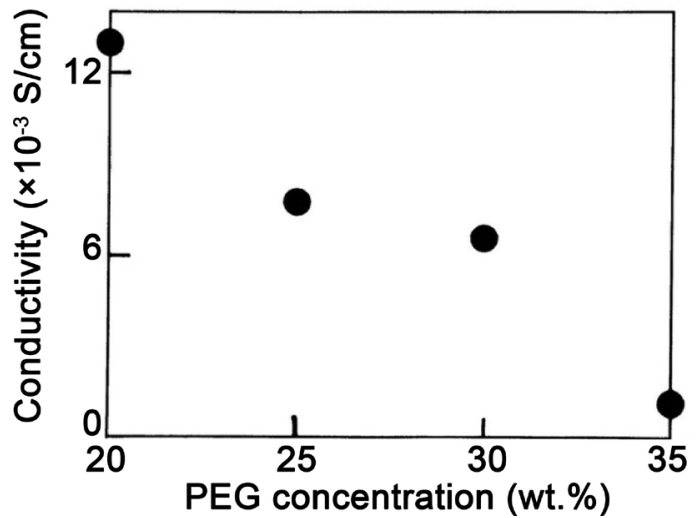

Figure 1. The dependence of the electrical conductivity on the PEG concentration. As the concentration decreases, the conductivity becomes larger. But if the PEG concentration is too low, the electrolyte is not be gelated.

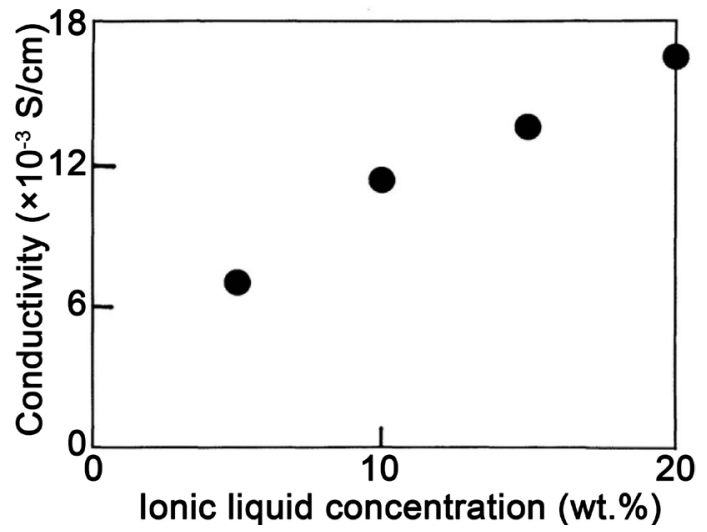

Figure 2. The dependence of the electrical conductivity on the concentration of ionic liquid. This figure shows positive correlation between them. However, the high ionic liquid concentration disrupts the gelation. 


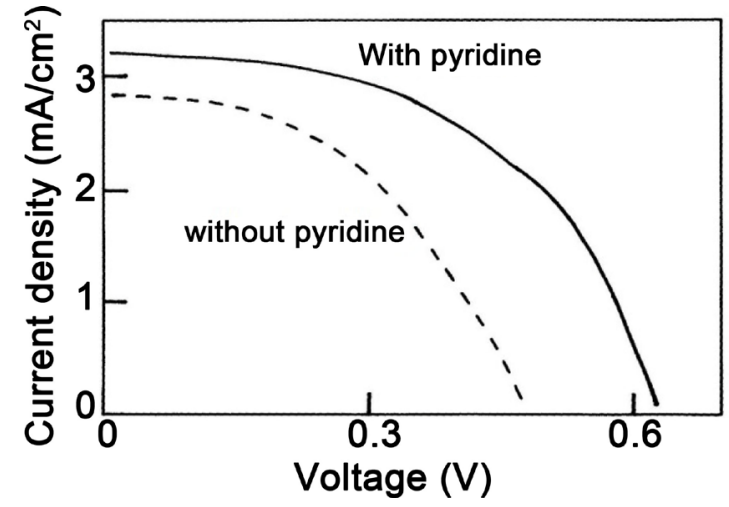

Figure 3. $J-V$ characteristics of DSCs. Doping pyridine enhances the short current density as well as the open voltage.

in this case. The figure tells us that the conductivity increases along with the concentration of the ionic liquid. The ionic liquid raised the electric conduction regardless of the increase of its viscosity.

We next show the effect of pyridine. Figure 3 shows $J-V$ characteristics of the cells including pyridine (20 wt.\%) and no pyridine for comparison. In this experiment, the concentrations of the ionic liquid and PEG were 20 wt.\% and 30 wt.\%, respectively. By introducing pyridine to the electrolyte, the open voltage increased from 0.48 to $0.63 \mathrm{~V}$ and the short current density increased from 2.77 to $3.10 \mathrm{~mA} / \mathrm{cm}^{2}$. We calculated the fill factor and conversion efficiency based on the data in Figure 3, and found that the fill factor increased from 0.48 to 0.53 and that the conversion efficiency increased from $1.17 \%$ to $1.91 \%$. Several researchers have studied on the effect of pyridine [11] [12] [13]. In many cases, the effect of pyridine only appears in the increase in the open voltage. But in our experimental results, the short current density also increased. We next discuss this unfamiliar behavior.

Taura et al. showed that pyridine enhanced the open voltage but reduced the short current density on the other hand [14]. Their results suggested that the adsorption of pyridine on the surface of $\mathrm{TiO}_{2}$ shifted the conduction band edge to a more negative potential, which led to the increase of the open voltage. This discussion can be applied to our result whereas acetonitrile was used as a solvent in their electrolyte. Our results also showed the increase in short current density by the addition of pyridine, which is contrary to their results. They owed the decrease to the weakening of light intensity into $\mathrm{TiO}_{2}$. Our results give a kind of doubt to their discussion. These two opposite results apparently suggests some effects of pyridine on the electrolyte. The mechanism of the enhancement of the short current density is now the issue to be studied. It is possibly related to the kind of solvent in the electrolyte.

We describe here the additional experiment that the ionic liquid was replaced by the one of the butyl-imidazolium system. Figure 4 shows $J-V$ characteristic under light exposure where the concentration of the ionic liquid was between $5 \mathrm{wt} . \%$ and $20 \mathrm{wt} . \%$. As the concentration increase, both the open voltage and the short current density increase gradually. Pyridine was also added in this experiment. 


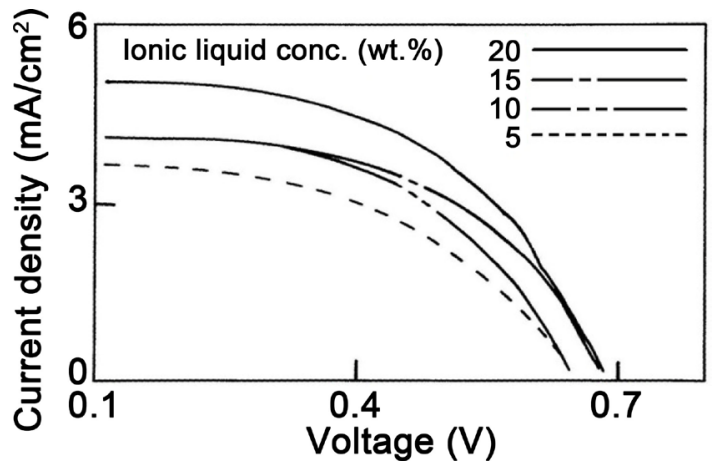

Figure 4. $J-V$ characteristics of DSCs. As the concentration of ionic liquid (a kind of butyl-imidazolium system) is higher, both the open voltage and the short current density are gradually enlarged.

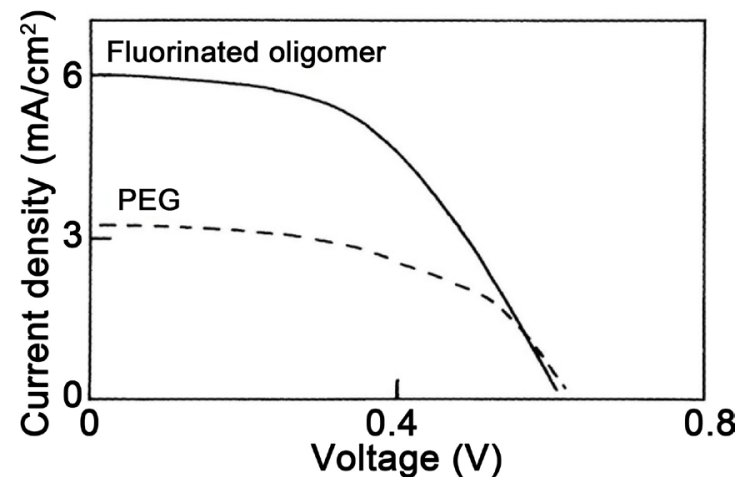

Figure 5. $J-V$ characteristics of DSCs. Fluorinated oligomer provides noticeably large short current density; twice as large as PEG for gelation.

Compared with Figure 3, both the open volt age and the short current density are larger. The difference in molecular structure of the ionic liquid affected these values.

Finally, we show the interesting experimental results that the PEG-based gel was replaced by a fluorinated oligomer gel electrolyte. The fluorinated oligomer gel electrolyte has been investigated mainly by our group so far [15]. The detailed preparation method of the electrolyte and the performance of the cell with this kind of electrolyte should be referred to the literature. The ionic liquid used in this experiment was back to that of an ethyl-imidazolium system. The difference in the $J-V$ characteristics between the two kinds of gel electrolytes are shown in Figure 5. It is surprising that the short current density enhances about twice by the replacement while the open voltage is not changed.

The fluorinated oligomer is linked with each other by both inter-molecular force between the bulky end groups and ionic attraction force between the side groups. As a result, it forms a bulky net structure including electrolyte or ionic liquid inside the net. The separation scheme into two micro phases is considered to enhance the ionic conduction in a gel state. In the case of PEG, long molecular chains attract each other to form a quasi-crystal state or a compact aggregated state so that there is little space for the electrolyte based on ionic liquid to move freely between the cathode and the anode. The fluorinated oligomer makes 
a good framework for the confinement of the electrolyte with keeping its free conduction.

\section{Conclusion}

We investigated a DSC using acetylacetone-based electrolyte. In order to increase the electric conduction in the electrolyte, the concentration of PEG should be low and that of the ionic liquid is required to be high. But in the extreme end, the electrolyte cannot be gelated. The addition of pyridine enhances not only the open voltage but also the short current density at the same time. When the ionic liquid was replaced by one of the butylimidazolium system, both the open voltage and the current density gradually increased up to $0.68 \mathrm{~V}$ and $5.04 \mathrm{~mA} / \mathrm{cm}^{2}$, respectively, as the concentration increased to $20 \mathrm{wt} . \%$. Finally, when the electrolyte was gelated with a fluorinated oligomer was used, the short current density leaped to $6.01 \mathrm{~mA} / \mathrm{cm}^{2}$. The fluorinated oligomer plays a prominent role to enhance the short current density. We expect the possibility of acetylaceton-based electrolyte gelated with the help of the fluorinated oligomer.

\section{Acknowledgements}

The authors wish to thank Prof. Hideo Sawada for the preparation of fluorinated oligomer of AMPS used in our experiments.

\section{References}

[1] Grätzel, M. (2003) Dye-Sensitized Solar Cells. Journal of Photochemistry and Photobiology C: Photochemistry Reviews, 4, 145-153. https://doi.org/10.1016/s1389-5567(03)00026-1

[2] Gong, J., Liang, J. and Sumathy, K. (2012) Review on Dye-Sensitized Solar Cells (DSSCs): Fundamental Concepts and Novel Materials. Renewable and Sustainable Energy Reviews, 16, 5848-5860. https://doi.org/10.1016/j.rser.2012.04.044

[3] Lee, J.-K. and Yang, M. (2011) Progress in Light Harvesting and Charge Injection of Dye-Sensitized Solar Cells. Materials Science and Engineering. B, 176, 1142-1160. https://doi.org/10.1016/j.mseb.2011.06.018

[4] McConnell, R.D. (2002) Assessment of the Dye-Sensitized Solar Cell. Renewable and Sustainable Energy Reviews, 6, 271-293. https://doi.org/10.1016/S1364-0321(01)00012-0

[5] Xia, J. and Yanagida, S. (2011) Strategy to Improve the Performance of Dye-Sensitized Solar Cells: Interface Engineering Principle. Solar Energy, 85, 3143-3159. https://doi.org/10.1016/j.solener.2009.10.005

[6] Kanaparthi, R.K., Kandhadi, J. and Giribabu, L. (2012) Metal-Free Organic Dyes for Dye-Sensitized Solar Cells: Recent Advances. Tetrahedron, 68, 8383-8393. https://doi.org/10.1016/j.tet.2012.06.064

[7] Shahid, M., Islam, S.-U. and Mohammad, F. (2013) Recent Advancements in Natural Dye Applications: A Review. Journal of Cleaner Production, 53, 310-331. https://doi.org/10.1016/j.jclepro.2013.03.031

[8] Zhang, Q. and Cao, G. (2011) Nanostructured Photoelectrodes for Dye-Sensitized Solar Cells. Nano Today, 6, 91-109. https://doi.org/10.1016/j.nantod.2010.12.007

[9] Hara, K., Horiguchi, T., Kinoshita, T., Sayama, K. and Arakawa, H. (2001) Influence 
of Electrolytes on the Photovoltaic Performance of Organic Dye-Sensitized Nanocrystalline $\mathrm{TiO}_{2}$ Solar Cells. Solar Energy Materials and Solar Cells, 70, 151-161. https://doi.org/10.1016/S0927-0248(01)00019-8

[10] Fukui, A., Komiya, R., Yamanaka, R., Islam, A. and Han, L. (2006) Effect of a Redox Electrolyte in Mixed Solvents on the Photovoltaic Performance of a Dye-Sensitized Solar Cell. Solar Energy Materials and Solar Cells, 90, 649-658. https://doi.org/10.1016/j.solmat.2005.01.020

[11] Koops, S.E., O’Regan, B.C., Barnes, P.R.F. and Durrant, J.R. (2009) Parameters Influencing the Efficiency of Electron Injection in Dye-Sensitized Solar Cells. Journal of the American Chemical Society, 131, 4808-4818. https://doi.org/10.1021/ja8091278

[12] Yu, S., Ahmadi, S., Sun, C., Palmgren, P., Hennies, F., Zuleta, M. and Göthelid, M. (2010) 4-Tert-Butyl Pyridine Bond Site and Band Bending on $\mathrm{TiO}_{2}(110)$. The Journal of Physical Chemistry C, 114, 2315-2320. https://doi.org/10.1021/jp911038r

[13] Huang, S.Y., Schlichthörl, G., Nozik, A.J., Grätzel, M. and Frank, A.J. (1997) Charge Recombination in Dye-Sensitized Nanocrystalline $\mathrm{TiO}_{2}$ Solar Cells. The Journal of Physical Chemistry B, 101, 2576-2582. https://doi.org/10.1021/jp962377q

[14] Taura, H. and Daiguji, H. (2010) Effect of Pyridine in Electrolyte on the CurrentVoltage Characteristics in Dye-Sensitized Solar Cells. Electrochimica Acta, 55, 3491-3496. https://doi.org/10.1016/j.electacta.2010.01.085

[15] Ohmukai, M. and Kyokane, J. (2014) Addition of Pyridine to Dye-Sensitized Solar Cell Including Fluorinated Oligomer Gel Electrolyte. Journal of Materials Science and Chemical Engineering, 2, 8-13. https://doi.org/10.4236/msce.2014.211002

Submit or recommend next manuscript to SCIRP and we will provide best service for you:

Accepting pre-submission inquiries through Email, Facebook, LinkedIn, Twitter, etc. A wide selection of journals (inclusive of 9 subjects, more than 200 journals)

Providing 24-hour high-quality service

User-friendly online submission system

Fair and swift peer-review system

Efficient typesetting and proofreading procedure

Display of the result of downloads and visits, as well as the number of cited articles

Maximum dissemination of your research work

Submit your manuscript at: http://papersubmission.scirp.org/

Or contact wjet@scirp.org 